\title{
God in Systematic Theology after Barth: Trends and perspectives
}

\author{
Rian Venter \\ University of the Free State, Bloemfontein, South Africa \\ rventer@ufs.ac.za
}

\begin{abstract}
The article gives an overview of the state of scholarship on God in Systematic Theology since Karl Barth. The aim is to identify trends and to raise the question about the possibility of new insights generated in theological research. The pluralistic nature of Systematic Theology is highlighted. Having mapped the crucial insights articulated by Barth, the author identifies five trends in theological thinking on God: the Trinitarian Renaissance, the rethinking of the attribute tradition, the irruption of the other, the coming of global Christianity, and the quest for interdisciplinarity. The article concludes with an evaluation of the developments and registers critical shifts in the reflection on God in Systematic Theology.
\end{abstract}

Key words

God; systematic theology; Barth; Trinitarian Renaissance; attribute tradition; global Christianity; alterity; interdisciplinarity

\section{Introduction}

Taking stock of developments in an academic discipline may be fruitful. An overview of the state of scholarship may identify the trends, and signal unexplored areas requiring further research. In an era marked by the need for conversation among various disciplines, such an endeavour may acquaint dialogue partners with resources available. In this article, I intend to undertake such a venture, knowing how audacious and perilous this might be. To map the terrain of reflection by Systematic Theology on God is not the easiest of tasks. However, at the same time, the complexity of the landscape should not paralyse the cartographer. Preliminary maps may help others refine the contours. I will briefly describe the contemporary 
state of Systematic Theology and justify the chronological starting-point, prior to identifying and discussing five major trends. I will then conclude with the question as to the possibility of new insights generated by Systematic Theology.

\section{Systematic Theology and God - plurality}

To sketch the face of the contemporary state of scholarship of academic disciplines has become a particularly challenging and virtually unmanageable assignment. The growth of knowledge and proliferation of divergent approaches do not allow easy profiling. Only one description may do justice to the contemporary state of a discipline such as Systematic Theology - plurality. Even a seemingly straightforward description of the task of this theological field - “... a conceptual articulation of Christian claims about God and everything else in relation to God, characterized by comprehensiveness and coherence" (Webster 2007:2) - refracts in practice in the most dazzling array of colours. ${ }^{1}$ The labels given to their theologies by scholars - confessional, post-liberal, radical orthodox, feminist, public, global, and African, to name but a few - intimate already something of the nature of the landscape to navigate.

If the relevance-identity dialectic underlying the task of Systematic Theology, and so well-articulated by Moltmann (1974:7-31), is utilized as initial entrance to the present horizon, something of the dynamics of the plurality becomes clearer. The identity of the Christian faith itself is not a fixed stable essence, but a complex narrative, which is creatively appropriated by people from different geographical and denominational locations, in their multiple identities of culture, gender, class, and with their diverse interests and values. The story of the plurality in Systematic Theology is one of place, perspective and interpretation. The spectrum of traditional "sources" of theology - Scripture, tradition, reason - has been expanded by an appreciation of experience (often perceived as historically suppressed) and by dialogue (with non-theological disciplines).

1 For one other definition by a theologian who wrote extensively on the nature of doctrine, see Vanhoozer (2005:773) - "Systematic Theology is the cognitive and passionate enterprise that seeks to know and love the God of the gospel and to demonstrate its understanding in forms of obedient speech and practice". 
It may be fruitful to briefly attend to two astute observers of the field of Systematic Theology for an orientation to the current state of the discipline. The Reformed theologian Smit (2013:387-398) suggests five trends: a selfcritical reflection on the Trinity in the Christian Faith; a confession of the Faith in light of numerous fundamental questions; a reaction to the "spirit of the times"; an understanding of the Faith in conversation with the "other", and attention to worship directed towards God. The Roman Catholic scholar Francis Schüssler Fiorenza (2011:64-74), in a fine overview, identifies five "decenterings" that have taken place in Systematic Theology, namely subjectivity, method, progress, the elites, and individualism. ${ }^{2}$ The discipline of Systematic Theology, like other fields of study, is pluralistic and dynamic, and resists simplistic representation, let alone easy distillations in the form of typologies.

The ramifications of this condition for the question about God are obvious. Drastic developments and shifts have taken place, which warrant careful attention, but no straightforward description is possible. A fairly large number of attempts to indicate trends and changes are available, but none are adequately comprehensive. ${ }^{3}$ Four examples of such discussions may be summarised to intimate new emphases and sensibilities, as well as the crucial role that a particular reading of society, religion or philosophy does play in the discourses on God. Gilkey (1982), a theologian with a sensitive antenna for changes in society, ${ }^{4}$ in a somewhat older treatment, highlights issues of knowledge, language, agency, temporality, and history. The influence of thinkers such as Hegel and Whitehead is pervasive: "God ... shares in the metaphysical categories of process: potentiality, change, relatedness, development, and dependence and passivity" (1982:79). Having discussed the well-known trajectories of, for example, death-of-God theologies and open theism, Kärkkäinen (2004) proceeds to focus his particular interest on contextual and non-Western approaches such as Native American,

2 The rich textures Smit and Schüssler Fiorenza accord to their respective interpretations cannot be summarised, in this instance, but should be pointed out.

3 See, for example, Schüssler Fiorenza (2001), Callen (2004), Reeling Brouwer (2011), and Venter (2012). It is interesting to note what issues are identified as "nuwe weë" by the South African theologian Durand (1976) in an older work: transcendence/immanence, personhood, Trinity, attribute tradition, suffering, and atheism.

4 See, for example his 1985 article in which he pleads for a "hermeneutic of events". 
Immigrant, Latina, African, and Asian perspectives. His work is a timely and fruitful retrieval of traditions ignored in standard and conventional textbooks. In an impressive "mapping (of) frontiers", Johnson (2007) discusses how experiences of suffering, poverty, and racism - in different contexts - determine talk about God. What makes her work particularly well textured is the inclusion of a discussion of religious pluralism and newer scientific cosmologies. With his interest in the intersection of theology and philosophy, Shults (2005:15-94) identifies three anxieties that have riddled thinking about God: the Cartesian (that is, about certain knowledge), the Ockhamist (about the notion of "person"), and the Newtonian (about the nature of causality).

\section{Barth and God - the Event who loves in freedom}

To start an overview of the reflections in Systematic Theology on God with Karl Barth (1886-1968) is a natural choice and requires hardly any justification. His position as major Protestant theologian of the twentieth century has been firmly cemented. A number of impulses emanating from his work are applicable to the focus of this investigation. His theology is an intentional reaction to nineteenth-century Liberal Theology, with its captivity to modernity, and as such functions as a bridge to a more postmodern approach, which subverts human reason in its drive to domesticate God. ${ }^{5}$ The basic, but decisive moves made by Barth should be carefully discerned. The doctrine of God is retrieved and located at the very beginning of the dogmatic enterprise (that is in Church Dogmatics 1/1), and this is done in a consistent Trinitarian manner. By doing this, "its content (becomes) ... decisive and controlling for the whole of dogmatics" (Barth 1975:303) and consequently "the basic presupposition of the doctrine of God” (:312). Furthermore, by doing so, he emphatically distinguishes a specific Christian understanding of God from a generic theistic one. ${ }^{6}$ The twenty-first-century quest for a "post-metaphysical" understanding of the divine is already prominently present in Barth's work. His resistance to

5 See the study of Johnson (1997) on God in Barth and his discussion of the postmodern foundations of theology already present in Barth's theology (esp. pp. 184-191).

6 For excellent studies of Barth's understanding of the Trinity, see the seminal work by Jüngel (2001) and Torrance (2000). The volume Trinitarian theology after Barth (Habets \& Tolliday 2011) represents in-depth and contemporary engagements with this aspect of his oeuvre. 
"the threatened absorption of the doctrine of God into a doctrine of being" is expressly pronounced (Barth 1957:260). Because God is who He is in the act of His revelation, Barth can hold being and act together, and can assert that "God's godhead consists in the fact that it is an event" (1957:263). God should be understood as event, as act, and as life (:264). When addressing the fundamental question what it is to be God, what makes God God and what is God's essence, Barth advances his well-known description of God as "the One who loves in freedom" (1975:257). Having argued this, he then proceeds to a discussion of the traditional attributes of God, or what he terms "perfections" of God. The manner in which this is executed should be carefully noted. Traditional attributes are dialectically "paired", for example, grace and holiness, mercy and righteousness, constancy and omnipotence. But, and this is crucial, the treatment follows the extensive Trinitarian exposition and the perfections are Trinitarianly interpreted. ${ }^{7}$ The difference this makes, is immense. Two examples may suffice to illustrate this. When interpreting the omnipresence of God, this new starting-point allows Barth to imaginatively introduce the notion of divine spatiality (Barth 1957:468-476) and to prefigure the central concern of the current "turn to space" and its connection with relationality. A Trinitarian interpretation of the glory of God, the "sum of all divine perfections", opens possibilities to refer to enjoyment and divine beauty (Barth 1957:650-666). Again, relationality prompts this: the form of the divine life, the triunity of God, "is the secret of His beauty". The ramifications of a re-visioning of divine attributes are vast: only these two examples allow for a theological contribution to questions about the built environment and to aesthetics. The title of the volume of essays - Dogmatics after Barth (Thomas, Reeling Brouwer \& McCormack 2012) - captures the situation of Systematic Theology; it is thinking and speaking God after the far-reaching insights of this theologian.

To describe the developments after Barth confronts one with various options. One may focus on major theologians who made particular contributions to the field with new insight, or on recurring themes and motifs being discussed, or on important texts that have become "classics" in the discipline. My decision is different from these possibilities, and comprises an awareness of intra-disciplinary, sociological, cultural and epistemological shifts that

7 For a study of the divine perfections in Barth's theology, see Price (2011). 
have taken place and decisively determined the course of thinking about God. Five major trends can be identified and the sheer volume of literature on each discourse may warrant such an approach. ${ }^{8}$

\section{Five trends on God}

\subsection{Trinitarian renaissance - the relational God who invites}

It took several decades before the insights of Barth came to fruition. A new interest in the doctrine of the Trinity is arguably the outstanding development in Systematic Theology of the second part of the twentieth century. Usually, the two Karls - Barth and Rahner - are credited with the motivation for this new appreciation. In a sense, their work presents similar intuitions: both felt uneasy with the term "person", and both insisted that God's eternal nature corresponds to God's salvific action in history. Rahner (1997[1970]:22) became especially known for his axiom that "the economic Trinity is the immanent Trinity and the immanent Trinity is the economic Trinity". A detailed history of the recovery of the Trinity may convey a more complex story, which credits Hegel and the German Idealists of the nineteenth century for the new interest, ${ }^{9}$ and which evidences a narrative of a doctrine never totally eclipsed since the Patristic era. ${ }^{10}$ That an exceptional enthusiasm for Trinitarian thinking captivated systematic theologians can hardly be missed from especially the 1970s onwards. Some excellent overviews record the state of scholarship. ${ }^{11}$

Some of the main features of this new interest should be identified. There is strong insistence that the specific Christian identification of God is unique - one God with a differentiated life of three persons, Father, Son and Spirit. The economy of the three Persons should be the starting-point

8 I am well aware of the preliminary nature of my proposal, and of the omissions. In a longer overview, I would also include discussions of theologians such as Hartshorne and contemporary process theologians, Tillich and Von Balthasar, as well as discourses on atheism and on the "open view" theology.

9 Sanders (2012:22-25) points to the three major ideas that gave this stimulus - world history, human experience, and the retrieval of the past - and the decisive influence of Hegel.

10 See especially Marshall (2004).

11 See O’Collins (1999), Grenz (2004), Kärkkäinen (2009), Phan (2011), Emery \& Levering (2011), and Schwöbel (1995 \& 2014). 
for a reflection about the nature of God, which forms the basis for the work ad extra. One encounters a particular appreciation for the Eastern tradition and the Cappadocian Fathers who prioritised "person", and not substance, in their metaphysics. This resulted in, arguably, the major tenet of this Renaissance - the emphasis on the relationality of God. ${ }^{12}$ God's very life is communion, and the traditional question about the unity of the three persons is addressed with the notion of perichoresis. The articulation of a "social doctrine of the Trinity" inevitably opened possibilities to explore the practical - that is, social - implications of this traditionally obscure doctrine.

Apart from the flood of practical applications, the scholarly spin-offs of the new valuation are significant. One encounters new studies on the Trinity and the Bible, ${ }^{13}$ the history of the early development up to Nicea, ${ }^{14}$ the theologies of major and influential thinkers such as Calvin, ${ }^{15}$ and neglected fields such as empire. ${ }^{16}$ A comprehensive work, The Oxford handbook of the Trinity (Emery \& Levering 2011), evidences the wide-ranging academic impact of the Trinitarian renewal.

In no way should this academic recovery of the Trinity in Systematic Theology be presented as a "peaceful" process. Most of the central elements identified are severely contested. The British theologian Holmes (2012b:2), for example, is outright hostile and claims: "I see the twentieth-century renewal of Trinitarian theology as depending in large part on concepts and ideas that cannot be found in patristic, medieval, or Reformation accounts of the doctrine of the Trinity." Apart from typical scholarly conflicts of interpretation, for example on Augustine's Trinitarian theology, major salvos are launched against both the social interpretations of the Trinity ${ }^{17}$ and the practical applications of the doctrine. ${ }^{18}$ For those accepting the

12 For a brief but excellent discussion of the "turn to relationality", see Shults (2005:5-9).

13 For a good overview, see Swain (2017).

14 The major study by Ayres (2004) deserves attention. Ayres \& Radde-Gallwitz (2008) summarize major new developments in Patristic Studies on God.

15 For example, Baars (2004).

16 See Rieger (2007, especially chapters $1 \& 2$ ).

17 For a good discussion, see Van den Brink (2014).

18 See Wisse (2011:3-10). 
political implications of the Trinitarian confession, a major dispute is whether it is a matter of "imitation" or "participation". ${ }^{19}$

Despite disagreements among systematic theologians, the questions generated by this discourse are pertinent to any serious doctrine of God. First, the claim of continuity with tradition raises the problematic as to whether the history of God in the development of human societies does not render fundamental shifts unavoidable and even preferable. Secondly, the transfer from first-order expressions (doxological descriptions) to secondorder reflection (ontological propositional statements) is inevitable. The Hellenization thesis of Von Harnack is no longer uncritically accepted. It is a natural development to articulate the content of faith in the metaphysical categories available at the particular time. The shift from substantial to relational ontology is arguably a most productive development. Apart from the fact that faith is expressed in an idiom more intelligible to contemporary people, ${ }^{20}$ the possibility does exist that a genuine new insight into the nature of Ultimate Reality can be gained. This is the argument made by Zizioulas (2008:47-69) in his interpretation of the Cappadocians: essence and person are co-fundamental, as there is no bare "essence". Identity can only be described in terms of relationships and, in this way, "the Trinity gives us the truth of our own existence" (:64). Thirdly, the advocacy for some form of analogical thinking between Trinity and society underlines the ethical consequences of discourses on God; they are never innocent; they do matter. Hardly anyone, let alone committed social Trinitarians, will claim a direct and un-nuanced line from monotheism to autocracy, or from Trinitarianism to democracy. In his well-known article with the provocative title "The Trinity is our social programme", Volf (1998:408) signals the direction for the link between Trinity and society: "What notion of identity is inscribed in the character and relation of divine persons?" With associations such as ex-stasis, mutuality, reciprocity, self-donation, gifting, and hospitality, the contours of a Trinitarian social ethic start to crystallize.

19 See, for example, Tanner (2012). She rejects social Trinitarianism and its insistence on the possibility of "imitating" God in society, but maintains the political ramifications in terms of "participation" in the divine life.

20 Cunningham (2003) argues the connection between postmodernity and relationality well. 


\subsection{Rethinking the attribute tradition - the hospitable God who suffers}

A discussion of divine attributes has been a constitutive part of the systematic treatment of the doctrine of God. ${ }^{21}$ This discourse has been under drastic reconstruction, especially since Schleiermacher. ${ }^{22}$ Unease has been increasingly expressed about the Greek metaphysical influence and whether a more dynamic and biblical determination is not required. Gunton (2002:2) conveys this sentiment with his view that "the Christian doctrine of God is for much of its history a hybrid of two organisms". ${ }^{23}$ Situating the discussion of attributes prior to an exposition of the Trinitarian confession, especially in Reformed Scholasticism, was fatal.

One encounters significant attempts to redress this and one can refer to some Dutch contributions in this regard. Under the influence of Brümmer, the so-called Utrecht School submitted an impressive rethinking of the attributes from an explicit personalistic perspective (Van den Brink \& Sarot 1995). The characteristics of God should be interpreted from the reality of a personal relationship. The consequences for an understanding of traditional notions such as immutability or omnipotence are obvious. In a splendid approach, Berkhof (1993:115-149) executes two moves: think about attributes from the notion of "encounter" ("ontmoeting") and juxtapose the characteristics, for example holy love, and vulnerable power ("weerloze overmacht"). In their comprehensive recent Dogmatics, Van den Brink and Van der Kooi (2012:137-144) accept the Trinity as "ordeningsprincipe voor de eigenschappenleer", but do not opt for a dialectical "pairing", preferring to view the properties of transcendence as qualifications of God's turning towards human beings (:144) ${ }^{24}$ In the recent monograph on God, Muis (2016) utilizes the Lord's Prayer as entrance to

21 For a good account of the scholarly history of the attributes since Early Modernity, see Holmes (2012a).

22 Attributes are not so much an expression of the nature of God, as an account of how God is experienced by human beings.

23 In a comparison of the "two theisms", Plantinga, Thompson \& Lundberg (2010:99-108) describe the differences well in terms of method, content and results: metaphysical causality vs revelation, timelessness and immutability vs communion, and determinism vs personalism.

24 The underlying assumption is to maintain a distinction between "hoogheids-" and "toewendingseigenschappen", or transcendence and condescension. 
his discussion of the attributes, and consequently discusses love, holiness, righteousness, power (“Gods macht”), and eternity.

Other thinkers such as Jüngel and Krötke are convinced that the attributes should be explored Trinitarianly. ${ }^{25}$ God's very divinity should be consistently viewed in terms of event and relationality. ${ }^{26}$ In addition, the narrative of the incarnation, with the cross as central feature, makes all the difference. Traditional attributes such as simplicity, immutability and omnipotence require radical re-interpretation. The interest in love as expressing something fundamentally true of the Christian God continues to interest theologians. ${ }^{27}$

It may be pertinent to mention, in this context, the seminal and wellknown contribution of Moltmann with his The crucified God (1974), which challenges the traditional doctrine of the impassibility of God. The cross is, in the first instance, an event between Father and Son and is not external to the "immanent Trinity"; that is, what happens in time affects the very divine life. A doctrine of divine passibility (capable of feeling, especially suffering) is required: God can be affected by creation; the nature of love makes suffering inevitable. Moltmann (1974:227) mentions that "God's being is in suffering, and the suffering is in God's being itself, because God is love". In line with the general orientation of his theology, the social applications are not far from Moltmann's (1974:222) mind: "For a God who is incapable of suffering is a being who cannot be involved." The dust has not settled with Moltmann's provocation and one encounters a spectrum of reactions, from outright rebuttals such as Weinandy's (2000) to careful and nuanced interactions such as Vanhoozer's (2010).

It may be justifiable to mention, in this context, a major insight: understanding God's "being" in terms of eschatology and explicitly the future. The contribution of Moltmann and Pannenberg can hardly be overstressed. In his magisterial Theology of hope (1967:16), Moltmann

25 For a good study of their theologies of the divine attributes, see Holmes (2007).

26 Only one example may suffice in this regard: Webster (2003:44f), a theologian with orthodox inclinations, but also with an express Trinitarian appreciation, emphasises that holiness is a relational concept. Such an interpretation might make quite a difference whether it refers to distancing or the opposite - involvement.

27 For a good discussion, see Vanhoozer (2001). 
argues that eschatology is "not one element of Christianity, but it is the medium of Christian faith as such". Prioritizing the notion of promise allows him to follow Bloch in viewing God with "the future as his essential nature" (1967:16). Because the future is something qualitatively different from what is experienced as history, it can function as a paradigm for transcendence (Moltmann 1969:196f). Pannenberg developed similar ideas, talking of God "as the power of the future" (1971:244), "future as a mode of God's being” (:242). In his later work (1991:401ff), Pannenberg argues that the eternity of God embraces God's futurity. ${ }^{28}$ The innovation of this perspective for a doctrine of God can hardly be over-emphasized. ${ }^{29}$

The crux of what is at stake in this discourse should be recognized: what are contemporary and primary associations with Ultimacy or the Divine, and what metaphysical or paradigmatic frames of reference inform the discussions? In simple language: what distinguishes God from creation? According to Greek metaphysics, this was fairly clear. The turn to relationality has complicated this, and the (critical) embrace of sensibilities of postmodern thought even further. The focus is not only on a re-interpretation of traditional attributes, but also on the possibility of novel characterization. It is noteworthy that an informed scholar such as Kärkkäinen (2014: chapter 14), in his mature work, extensively attends to "divine hospitality". Changing times may encourage imaginative retrievals of resources from tradition, in order to characterize the divine in new ways.

\subsection{Irruption of the other - the disabled God who liberates}

The impulses wrought by Barth do have stark limitations. Systematic Theology, especially since the 1960s, has decisively started to move "beyond the pale". ${ }^{30}$ A new way of doing theology emerged, one which starts with

28 For a detailed discussion of "God of the future" in Pannenberg's theology, see Mostert (2002:127-182). For a wider discussion in Lutheran theology, see Shults (2003).

29 Kasper (1977:7) opines: "Gott und die Zukunft. Kaum ein anderes Thema is mehr characteristisch für die Umbrüche und Neuorientierungen, die sich in der protestantischen wie in der katholischen Theologie des 20. Jahrhunderts ereignet haben." It is a question whether this fundamental insight has not been eclipsed by other optics.

30 See the volume of critical essays entitled Beyond the pale: Reading theology from the margins (De la Torre \& Floyd-Thomas 2011), which interacts with theologians throughout history, indicating how their social location determined their theologies. 
the concrete historical experiences of exclusion, marginalization and discrimination. In this instance, the "de-centerings" mentioned by Schüssler Fiorenza come into view. The suffering people experience because of their sex/gender, race, poverty (class), and physical disability becomes the optic to reflect on their faith in God. For lack of a common denominator to name this trend, I suggest it is discussed with reference to alterity, and refer to discursive exclusion due to social or material identities and conditions. ${ }^{31}$

This development amounts to a major shift in theology. The literature on each one of the "exclusions" and their respective theologies is, understandably, virtually impossible to master. The evolving trajectories and the geographical identities complicate the situation. Johnson's (2007) work provides good bibliographies, but also with conspicuous omissions, for example, disability and sexual orientation. I can merely make some suggestions to convey the importance and productivity in this regard for gender, ${ }^{32}$ race, ${ }^{33}$ class, ${ }^{34}$ disability, ${ }^{35}$ and sexuality. ${ }^{36}$ What makes for interesting and unsettling reading is a comparative glance at recent comprehensive "Dogmatics". ${ }^{37}$ Alterity, in its manifold manifestations, is often conspicuously absent. The volume by the USA workgroup on Constructive Christian Theology Constructive theology (Jones \& Lakeland 2005) - is an exception and is one of the few projects to take plurality and alterity seriously.

What this new sensibility may point to for a doctrine of God should be examined. At least three such ramifications may be intimated. One,

31 Rieger (2001) situates this unfinished "turn" perceptively to various other "turns" in theology; for example, to the self, to the Wholly Other, and to language and the text.

32 For a good general introduction, see Grey (2001). For creative re-interpretations, see McFague (1987) and Johnson (1992). For an informed overview of feminist Trinitarian theology, see Bacon (2012).

33 For representative treatments of God in Black Theology, see Jones (1987) and Maimela (1991). For interesting discussions of the Trinity in the theology of Cone and Hopkins, see McGee (2016) and Buhring (2012), respectively.

34 For a thorough study, see Araya (1987), who refers extensively to L \& C Boff, Dussel, Ellacuría, Gutiérrez, and Sobrino.

35 On the notion of a "disabled God", see Cooper (1992), Eiesland (1994), and Swinton (2011).

36 For an important recent study from the perspective of Trinitarian Theology and Queer Theory, see Tonstad (2016).

37 To mention only a few published during the past few years: Horton (2011), Van den Brink \& Van der Kooi (2012), and Thiselton (2015). 
thinking and speaking about God can never be divorced from power. Alterity demands a new epistemology, a conception of knowledge that acknowledges location, perspective, and resistance. Any doctrine of God without - at least implicitly - a critical epistemology would be inadequate. A farewell to seemingly innocent and objective knowledge of God is unavoidable. Knowing God should be mediated by the face of the other. Two, a new vision of God has been emerging. A critical hermeneutic of alterity resulted in a re-reading of Scripture and tradition, exploring the surplus of meaning in texts and discovering resources of solidarity, vulnerability, justice, and liberation, for example, exodus, exile, migration, empire, and crucifixion. These texts teem with gender, ethnic, and bodily dynamics. The challenge for Systematic Theology is to integrate these motifs into constructive proposals. The central role of language should be pointed out. At stake is the very possibility of speech about God, ${ }^{38}$ and the performative function of language. This may entail intentional re-naming (for example, work by McFague or Johnson), ${ }^{39}$ or the retrieval of a central theme (for example, such as life in the work of Gutiérrez [1991]). It is striking how justice remains underdeveloped in a treatment of the attributes. ${ }^{40}$ One may even raise the question as to whether a belated theological correction is not being manifested in this discourse, one that is much more in step with the thrusts of biblical narratives. Taking alterity seriously means embracing the constructive nature of Systematic Theology. Three, the function of God - discursively - has changed. God is more than the heuristic symbol to explain the world or bring existential meaning; ${ }^{41}$ God disrupts, judges, comforts, and empowers; ${ }^{42}$ images of God function; ${ }^{43}$ attention to the ethical performance of theological constructs must be attended to and

38 Jüngel's (1983) theology is relevant in this regard. He explores the "speakability of God" in relation to the humanity of God, love and the Trinity.

39 McFague's (1987) alternative renaming is well-known - God as Mother, Lover and Friend. Johnson's (1992) proposal - SHE WHO IS - involves a multidimensional reinterpretation, one that employs the Sophia tradition and Trinitarian theology.

40 For one exception, see the work of the Christian philosopher Wolterstorff (2006).

41 For the "functions of the symbol 'God"”, see Kaufman (1993:301-31). Despite his plea for a "new conception of God", one cannot but escape the impression that his proposal for a "humanising" and "relativising" symbol remains a-historical.

42 Carr (1981) suggests the notion of the "God who is involved" to capture a general trend in theology.

43 See Venter (2008a). 
accounted for. No responsible doctrine of God can suppress an estimation of its performative effects.

\subsection{Coming of global Christianity - the postcolonial God who heals}

Mapping the shifts in the Systematic Theological discourse on God needs not only the assistance of metaphysics and cultural theory, but also sociology of religion to register the radical geographical and demographical mutations Christianity has been experiencing. The so-called "shift to the South" has transformed the face of Christianity, and the reception of the Christian God in Africa, Asia and South America warrants study. At least four challenges are confronting Systematic Theology: the translation of God in non-Western categories; the encounter with indigenous and other world religions; the needs of Pentecostal and Charismatic believers, and the quest for postcolonial theologies.

This relatively new situation means "the end of Systematic Theology"44 and significant work has already been undertaken on Global Theology and God. ${ }^{45}$ Arguably, the most impressive Systematic Theology written in this respect is the 5-volume project A constructive Christian theology for the pluralistic world (2013-2017) by the Finnish scholar Kärkkäinen. His explicit assumption is that the world for theology has changed; that the voice of theologians from the South should be attended to, and that world religions are important conversation partners. His conviction is one of "delight in the potential of an encounter with the other without denying either parties' distinctive features" (2014:356). ${ }^{46}$

What this "global turn" in the doctrine of God entails can be briefly described with reference to Africa. The great historian of Christianity in the non-Western world, Andrew Walls (2002:119-129), has perceptively described the actual dynamics of the encounter of Christianity and African

44 See the groundbreaking article by D'Costa (1992) with this title. He correctly anticipated that "the future of Christian Systematic Theology goes with a whole range of new partners" and that the Christian doctrine of God would come under "severe questioning" (:326, 331).

45 See especially Jeanrond \& Lande (2005) and Hintersteiner (2012).

46 Reference to the work by his predecessor at Fuller - Volf (2011) - on the relationship with Islam should be made. Volf's concern is that emphasis on "different Gods" increases the potential for hostility and violence. 
(Traditional) Religion. The elements of the religious map in Africa - God, divinities, ancestors and objects of power - have not been replaced; they have been reconfigured. The God-component was magnified, the divinities demonized, the ancestors continued, and the objects of power drawn into the Christian world. This re-ordering has continued access to power, prosperity, and protection. This may also explain the attractiveness of Christianity and the growth of Pentecostalism with the emphasis on power, healing and prosperity. The reception of the Trinity has found, interestingly, wide favour among African theologians, and creative re-interpretations have been submitted. ${ }^{47}$ The association of the Trinity with communion is appealing in an African context where relationality is valued. Some African scholars such as Nyamiti have attempted to furnish an alternative ontology, based on ancestor ship. ${ }^{48}$ To my knowledge, no thorough African postcolonial reflection on God has been produced. ${ }^{49}$ However, with the current insistence on decolonizing theology, one may expect this soon.

This discourse on Global Theology focuses on a new set of themes that invariably impacts on the traditional doctrine of God. The relation to other construals of Ultimacy cannot escape scrutiny; neither theology's indebtedness to Greek metaphysics and to modernity, and its involvement in the colonial project. In addition to the motifs conventionally associated with these manifestations of the Christian faith, Amos Yong (2014), the American Vietnamese theologian, employs "renewal" as label for his Global Theology.

\subsection{Quest for interdisciplinarity - the impossible God who gives life}

In a sense, theology has never been practised in isolation. Since the earliest accounts, the interaction with philosophy has been a constant conversation partner. This intensified in the late twentieth century. The realization of the fragmented nature of academic disciplines and the complexity of social problems have increasingly prompted theology to embrace the field of interdisciplinarity. This has developed to such an extent that several clear

47 Vähäkangas (2000) gives a good overview of older work. For more recent interpretations, see Kombo (2009) and Kunhiyop (2015).

48 For a description of this, see Venter (2008b).

49 Rivera (2007) has offered a "postcolonial theology of God", but mainly with South American interlocutors. 
discourses can be identified. For the purpose of this article, three such conversations can be attended to - those between Systematic Theology and the sciences, Continental Philosophy of Religion, and Spirituality. ${ }^{50}$ Each one of these interactions has resulted in the generation of new questions and sensibilities.

1. The dialogue between theology and science has become a vibrant field of academic inquiry, with even several "generations" of scholars involved, each with its own concerns and contributions. Pertaining to the question of God, at least three foci can be singled out. One, the scientific acceptance of an evolutionary, quantum and emergent cosmology, the traditional views of God's relationship to the world, and divine action in the world have become hugely problematic. Deistic, monarchical or interventionist models of Godworld interaction have become untenable, and the quest is for more intersubjective and organic approaches. ${ }^{51}$ This question is obviously not only one of relationship, but also one of the nature of God's action in a cosmos that is simultaneously intelligible in terms of "laws", but also indeterminate and contingent. The massive research project on "Divine Action" undertaken by the Vatican Observatory and the Centre for Theology and the Natural Sciences (Berkeley), which resulted in seven volumes of proceedings, is particularly important

50 One could refer to at least two more dialogues. The conversation with the Arts is a fairly new field of study, and the discussions centre on various notions of transcendence. The second one with Biblical Studies is obviously crucial, but also complex. In an excellent treatment from the perspective of the New Testament, Rove \& Hays (2007) point to the shifting relationship - from unity to separation to unity and separation. Their view is that because of "the subject matter ... the two disciplines are of necessity inseparable", but remain "dialectical". They plea for "exegetical thickness of doctrine and the theological coherence of biblical exegesis" (:452). The irony of the current enthusiasm for interdisciplinarity is that the conversation with Old and New Testament as academic fields of study with their respective histories of scholarship is, in fact, unexplored. Two examples could illustrate this. The sensitivity to the "dark side" of God, the so-called "counter-testimony", in the Old Testament has not been addressed Trinitarianly. Systematic Theology has not engaged narratological interests in New Testament Studies, and its application to God as character. This conversation, reconfigured as one between various disciplines, could open fruitful perspectives for a reflection on God.

51 For a discussion of the various models, see McFague (1993:136-141) who proposes a new appreciation for seeing the world as "God's body". 
in this regard.$^{52}$ It is clear from this project that there is basically no position of agreement on the quest for a "casual joint", but at the same time the conviction of divine presence and agency is not abandoned; it has only been complicated. Resistance to miraculous intervention cannot be missed in the discourse..$^{53}$ Two, as a result of these investigations, the notion of panentheism has acquired special currency, but also resulted in severe contestation. Panentheism intends to maintain a distinction between God and world, but at the same time advocates an inextricable intertwining that expresses process, mutuality and reciprocity better than classical theism. ${ }^{54}$ Three, the engagement with ecology as dialogue partner emerged with urgency, and the direction of interfacing with the doctrine of God is obvious. As the very life of the planet is under threat, theologies of life are formulated and God is named as the "God of life" 55 .

2. The "theological turn" in Continental Philosophy of Religion ${ }^{56}$ amounts to one of the most important contemporary probing into the nature of the divine, and one that confronts theology with serious self-examination. Some of the most creative thinkers in this discourse are Marion, Caputo and Kearney. ${ }^{57}$ The interplay between a radical critique of the metaphysical tradition by Heidegger with his notion of onto-theology, the views of Derrida on "gift" and "hospitality", and the general ethical "turn to the other" in French philosophy by Levinas and Ricoeur have deeply impacted reflection on the divine.

52 See the last two volumes that attempt at bringing order amidst a bewildering diversity of views: Russell, Murphy \& Stoeger (2008), and Shults, Murphy \& Russell (2009).

53 For an informed discussion, see the work by Conradie (2010, especially the summaries 157ff, 239ff).

54 For excellent and sympathetic discussions, see the volume by Clayton \& Peacocke (2004). For a detailed historical treatment, with an eventual defence of classical theism, see Cooper (2006).

55 For an outstanding example of this re-naming, see Conradie (2013) who regards the genitive - God of life - as descriptive, that is, life is one of God's salient characteristics, implying "God is the One who is the origin of life, God is the one to whom life belongs, and God is the One who is the giver of (new) life" (:5).

56 The standard account in this regard is the volume by Janicaud (2001).

57 For an informed account that furnishes the philosophical background as well as excellent descriptions of the proposals by the main participants, see Gschwandtner (2013). 
The series of debates at the Villanova University and the consequent publications represent some of the most penetrating academic encounters on God of recent time..$^{58}$ The quest for a post-metaphysical notion of God may arguably be the central issue. Heidegger's concern about the onto-theological constitution of Western metaphysics - that is, no proper separation between Being and beings, and an inability to assert true Alterity without reducing Transcendence to more of the same - has started to haunt philosophers of religion. Marion's seminal work God without being (1991) signals the direction to go: a conception of the divine that could be understood beyond the horizon of being. His alternative that "gift" and "saturation" are the preferred categories has become hugely influential. For the vast majority of these thinkers, the target for revision is the "three-headed monster of metaphysics - the Omni-God of omnipotence, omniscience, and omnipresence". ${ }^{59}$ Caputo's proposal in his primary work The weakness of God (2006) is for a God without sovereignty who is a weak force. The "theopoetics" of Kearney, as expressed in works such as The God who may be (2001) and Anatheism (2010), contracts all the major motifs of this discourse in his own imaginative proposal. There is an emphatic departure from the Omni-God of theodicy and of metaphysical causality, and an intentional retrieval of the perspectives of promise and futurity. His "God after God" calls for acts of charity, in everyday life and in hospitable encounters with the "least of these". The combination of concerns in this discourse - critique of onto-theology, gift and saturation, as well as alterity and hospitality intimates a serious challenge and encouragement to traditional Systematic Theology to re-think God in a post-metaphysical manner. ${ }^{60}$

3. The "turn to spirituality" in the twentieth century and the decline of conventional denominational religiosity did not escape the radar of Systematic Theology, and intentional interactions with especially spirituality and mysticism are found. I will attend to the work of two

58 See Caputo \& Scanlon (1999 \& 2007) and Caputo, Dooley \& Scanlon (2001).

59 See Manoussakis (2006:xvi).

60 For some interactions, see Henriksen (2010), Benjamins (2015) and, by South African scholars, Steenkamp (2017), Verhoef (2017), and Pretorius (2018). 
prominent systematic theologians who also happen to be outstanding God-thinkers.

David Tracy is one of the truly noteworthy God-thinkers in contemporary theology. His work displays a firm grasp of the history of doctrine and of the unique contours of the present time. Overcoming the separation of theology and spirituality forms a main orientation in his mature theology. For Tracy (1994:37), the history of theology is the history of the ever-shifting relationship between the reality of God and that reality as understood from within a specific logos, that is, a horizon of intelligibility. He feels inclined towards postmodernity, as it resists the totalizing system of modernity and attends to the face of the other (Tracy 2002:27). Although he expresses appreciation for the emphasis on relationality in recent theology, he is worried that God may become yet again a conceptual prisoner of this system of thinking (1994:42). His preferable category for speaking about God is the Impossible, as it allows a naming of God in terms of incomprehensibility and hiddenness (Tracy 2011:124). The two theologians epitomizing these notions in history are Dionysios and Luther. Tracy's central concern is to resist the eclipse of theos by the modern logos for intelligibility. He is seeking "a return of God", a "radical interruption" (Tracy 1994:42), "to let God be God again" (:44). This he finds in the postmodern form of the Impossible, "the reality of God as the incomprehensible, hidden and excessively loving one" (Tracy 2011:127). Two kinds of experiences are crucial for him: the "void" experiences of extreme suffering, injustice, terror, despair and alienation and the "open" - experiences of awe, wonder and sheer giftedness (Tracy 2002:28). Approaching God involves more than predication, but also praise and prayer. These he encounters in different fragments, in a variety of forms such as the lament, apocalyptic, and apophatic. He has particular openness to the Eastern Orthodox tradition and its attempt to combine apophaticism and Trinity (Tracy 2000:78) and he wants to "wonder again at the overwhelming mystery of God" (Tracy 1994:46).

The oeuvre of Sarah Coakley represents one of the most exciting and versatile projects under way in Systematic Theology at present. Her insistence on prayer as central to the Trinity warrants close reading. Integrating Patristic Theology, feminist theory, mysticism, iconography, and contemporary Systematic Theology, she remarkably pursues interdisciplinary theology with the label théologie totale. Her book - God, sexuality, and the self (an 
essay "on the Trinity") (2013) - together with the earlier mentioned fivevolume work by Kärkkäinen represent the dynamic nature and direction of current Systematic Theology. She connects the revival of Trinitarian thought to the renewal of the commitment to apophatic prayer. For her, and she is emphatic about this, prayer-practice is inherently Trinitarian. A detailed interpretation of Romans 8 allows her to develop a prayer-based model of the Trinity, starting with the Holy Spirit (2013:111-115). The combination of Trinity and prayer unavoidably confront a range of issues about sexuality. Her argument should be followed, in this instance: this engagement arises from the entanglement of human sexual desire and the desire for God. A new vision of divine desire (that is, a Trinitarian one) may provide the governing framework for a new approach to human sexuality. ${ }^{61}$ She constructs nothing less than a "Trinitarian ontology of desire" (2013:6). A number of crucial insights should be registered: Trinity and prayer have social and even cosmic significance (2013:114), and the focus on prayer is her answer to the danger of onto-theology (2013:42-47), as it resists turning God into a controllable object of knowledge.

\section{Gathering fragments - a new grammar for speaking God?}

To end this overview of main developments in Systematic Theology on God, some concluding comments may be productive.

1. The plurality of discourses and perspectives should in no way be considered a dilemma to overcome. The nature of the divine pluralizes human naming and resists domestication by simplistic and stable speaking. Kaleidoscopic descriptions convey much more a sense of authenticity as God stimulates rather than stifles the human imagination.

2. That radical shifts have taken place in the doctrine of God should be acknowledged. I refrain from drawing a new "profile" of God, which would be an expression of a totalizing mentality. However, thinking about God reflects the reality of deep global, social and cultural changes, and of reaction to classical theism. There are new trends,

61 Coakley (1998) succinctly discusses the main contours of her theology of Trinity, prayer and sexuality. 
new directions and new sensibilities which are widely acknowledged. Saying this, I do not pretend that consensus is inherent in the practice of doing Systematic Theology.

3. The profile or image of God, which emerges in the theology of serious God-thinkers, is the configuration of various elements. The transformation has occurred at the social and intellectual condition of production. An expansion has taken place - of geography, of thought categories, of hermeneutical paradigms, of experiences, of ethical concerns, and of dialogues with other disciplines. Much of this has happened intentionally, with a heightened awareness of the dynamics of theological construction.

4. Yet, despite the bewildering pluralization, the entire endeavour has not degenerated in an anarchical speaking, because there remains a centripetal force in Christian Systematic Theology - reference to the historical figure of Jesus. This central orientation, especially on the cross, renders the many sounds into a magnificent symphony. The re-appreciation of the Trinitarian confession, and the employment of a new - relational - ontology is a new translation of a persistent narrative of a "God who is for us".

5. The direct consequence of this "rediscovery" of the Trinity - the "revisioning" of the attribute tradition - could arguably be the outstanding contribution of the developments since Barth. The material result of an expansive formal condition is to be found precisely here. Thinking the divine Trinitarian disrupts conventional theistic speaking. Resistance to an onto-theological logic - that God is another being in the hierarchy of being - directed theologians back to narratives of interpersonal encounters in the Bible, to the cruciform nature of the Christian grammar, and to the fundamental eschatological orientation of the Christian faith. If one could dare to speak about "progress" in theology, it should be located here.

6. The preference of contemporary theologians to speak the Christian God in terms of relationality, vulnerability, futurity, gift and hospitality may reflect a sensitivity to listening more carefully to biblical witnesses and to discern more responsibly the heartbeat of our times. 
7. The intuitions and conviction of theologians led to two radicalizations: the immanence and the transcendence of God. God cannot be thought as outside of history or of cosmic processes; God is more intimately involved than we could grasp; yet, God is also more transcendent, more hidden than we could imagine. This dialectic of solidarity and of distance belongs to the fabric of the Christian identification of God.

8. Speaking God, naming God is an intrinsic ethical practice - it has unfathomable existential, social and planetary ramifications. Godtalk matters in a time of eco-recklessness, economic disparity, human displacement, multiple violence, and alienation. The choice of metaphors has political implications. The grammar of our theologies may embody an ethic of social responsibility.

9. The entanglement between God-construction and self-construction should not be missed. Far from being a mere human projection, the Christian Trinitarian naming is a statement of the ultimate mystery of the world. Naming God in categories intelligible to our time relationality, vulnerability, futurity, gift, and hospitality - returns as imperative to us: to "echo" something of those divine qualities as image-bearers. A vision of God and a vision of life go together.

10. The "new" grammar may also start suffering from aging and becoming a mere naming of the "Ancient of Days". Speaking God is a journey of receptive listening to the tradition, of responsible discerning the signs of the times, and of creative imagining. This is the joy of doing Systematic Theology in the face of Loving Mystery.

\section{Bibliography}

Araya, V. 1987. God of the poor. Maryknoll, NY: Orbis.

Ayres, L. 2004. Nicaea and its legacy: An approach to fourth-century Trinitarian theology. Oxford: Oxford University Press.

Ayres, L. \& Radde-Galwiz, A. 2008. Doctrine of God, in Harvey, S.A. \& Hunter, D.G. (eds.), The Oxford handbook of early Christian studies, 864-885. Oxford: Oxford University Press. 
Baars, A. 2004. Om Gods verhevenheid en zijn nabijheid: De Drie-eenheid by Calvijn. Kampen: Kok.

Bacon, H. 2012. Thinking the Trinity as resource for feminist theology today. Cross Currents 62(4): 442-464.

Barth, K. 1957. Church Dogmatics II/1. Edinburgh: T\&T Clark.

Barth, K. 1975. Church Dogmatics I/1. Edinburgh: T\&T Clark.

Benjamins, R. 2015. The post secular and Systematic Theology: Reflections on Kearney and Nancy. International Journal of Philosophy and Theology 76(2):116-128.

Berkhof, H. 1993. Christelijk Geloof. $7^{\text {th }}$ ed. Nijkerk: G.F. Callenbach.

Buhring, K. 2012. The spirit of resistance: Dwight N Hopkins's Trinitarian framework. Black Theology 10(2):184-194.

Callen, B.L. 2004. Discerning the divine: God in Christian theology. Louisville: Westminster John Knox.

Caputo, J.D. 2006. The weakness of God: A theology of the event. Bloomington: Indiana University Press.

Caputo, J.D. \& Scanlon M.J. (eds.) 1999. God, the gift, and postmodernism. Bloomington: Indiana University Press.

Caputo, J.D. \& Scanlon M.J. (eds.) 2007. Transcendence and beyond: A postmodern inquiry. Bloomington: Indiana University Press.

Caputo, J.D., Dooley, M. \& Scanlon M.J. (eds.) 2001. Questioning God. Bloomington: Indiana University Press

Carr, A. 1981. The God who is involved. Theology Today 38(3):314-328.

Clayton, P. \& Peacocke, A. (eds.) 2004. In whom we live and move and have our being: Panentheistic reflections on God's presence in a scientific world. Grand Rapids: Eerdmans.

Coakley, S. 1998. Living into the mystery of the Holy Trinity: Trinity, prayer, and sexuality. Anglican Theological Review 80:223-232.

Coakley, S. 2013. God, sexuality, and the self: An essay "On the Trinity". Cambridge: Cambridge University Press. 
Conradie, E.M. 2010. Lewend en kragtig: In gesprek oor ... God se handelinge in die wêreld. Wellington: Bybel-Media.

Conradie, E.M. 2013. The God of life: A counter-intuitive confession. The Ecumenical Review 65(1):3-16.

Cooper, B. 1992. The disabled God. Theology Today 49(1):173-182.

Cooper, J.W. 2006. Panentheism: The other God of the philosophers - from Plato to the present. Grand Rapids: Baker.

Cunningham, D.S. 2003. The Trinity. In: K.J. Vanhoozer (ed.), The Cambridge Companion to Postmodern Theology, 186-202. Cambridge: Cambridge University Press.

D'Costa, G. 1992. The end of Systematic Theology. Theology (95)767:324334.

De La Torre, M.A. \& Floyd-Thomas, S.M. (eds.) 2011. Beyond the pale: Reading theology from the margins. Louisville: Westminster John Knox.

Durand, J.J.F. 1976. Die lewende God: Wegwysers in die dogmatiek. Pretoria: NG Kerkboekhandel.

Eiesland, N.C. 1994. The disabled God: Toward a liberating theology of disability. Nashville: Abingdon.

Emery, G. \& Levering, M. 2011. Introduction. In: G. Emery \& L. Levering (eds.), The Oxford handbook of the Trinity, 1-12. Oxford: Oxford University Press.

Gilkey, L. 1982. God. In: P. Hodgson \& S. Sykes (eds.), Christian Theology: An introduction to its traditions and tasks, 62-87. London: SCM.

Gilkey, L. 1985. Events, meanings and the current tasks of theology. Journal of American Academy of Religion 80(4):717-734.

Grenz, S.J. 2004. Rediscovering the triune God: The Trinity in contemporary theology. Minneapolis: Fortress.

Grey, M. 2001. Introducing feminist images of God. Cleveland, $\mathrm{OH}$ : Pilgrim. 
Gschwandtner, C.M. 2013. Postmodern apologetics: Arguments for God in contemporary philosophy. New York: Fordham University Press.

Gunton, C. 2002. Act \& being: Towards a theology of the divine attributes. Grand Rapids: Eerdmans.

Gutiérrez, G. 1991. The God of life. Maryknoll, NY: Orbis.

Habets, M. \& Tolliday, P. (eds.) 2011. Trinitarian theology after Barth. Eugene, OR: Pickwick.

Henriksen, J-O. 2010 Thematizing otherness: On the ways of conceptualizing transcendence and God in recent philosophy of religion. Studia Theologica 64:153-176.

Hintersteiner, N. (ed.) 2012. Thinking the divine in interreligious encounter. Amsterdam: Rodopi.

Holmes, C.R.J. 2007. Revisiting the doctrine of the divine attributes: In dialogue with Karl Barth, Eberhard Jüngel, and Wolf Krötke. Frankfurt am Main: Peter Lang.

Holmes, S.R. 2012a. Divine attributes. In: K.M. Kapic \& B.L. McCormack (eds.), Mapping modern theology, 47-65. Grand Rapids: Baker.

Holmes, S.R. 2012b. The quest for the Trinity: The doctrine of God in Scripture, history and modernity. Downers Grove: InterVarsity.

Horton, M. 2011. The Christian Faith. Grand Rapids: Zondervan.

Janicaud, D. et al. 2001. Phenomenology and the "theological turn": The French debate. New York: Fordham University Press.

Jeanrond, W.G. \& Lande, A. (eds.) 2005. The concept of God in global dialogue. Maryknoll, NY: Orbis.

Johnson, E.A. 1992. SHE WHO IS: The mystery of God in feminist theological discourse. New York: Crossroads.

Johnson, E.A. 2007. Quest for the living God: Mapping frontiers in the theology of God. London: Continuum.

Johnson, W.S. 1997. The mystery of God: Karl Barth and the postmodern foundation of theology. Louisville: Westminster John Knox. 
Jones, M.J. 1987. The color of God: The concept of God in Afro-American thought. Macon: Mercer.

Jones, S. \& Lakeland, P. (eds.) 2005. Constructive theology. Minneapolis: Fortress.

Jüngel, E. 1983. God as the mystery of the world. Grand Rapids: Eerdmans. Jüngel, E. 2001. God's being is in becoming: The Trinitarian being of God in the theology of Karl Barth. (translation by J. Webster). Grand Rapids: Eerdmans.

Kärkkäinen, V-M. 2004. The Doctrine of God: A global introduction. Grand Rapids: Baker.

Kärkkäinen, V-M. 2009. The trajectories of the contemporary “Trinitarian Renaissance" in different contexts. Journal of Reformed Theology $3: 7-21$

Kärkkäinen, V-M. 2014. Trinity and revelation. Vol 2. A constructive Christian theology for the pluralistic world. Grand Rapids: Eerdmans.

Kasper, W. 1977. Gott und die Zukunft. In: M. Hengel \& R. Reinhardt (Hg.), Heute von Gott reden, 7-24. München: Kaiser.

Kaufman, G.D.1993. In face of mystery: A constructive theology. Cambridge, MASS: Harvard University Press.

Kearney, R. 2001. The God who may be: A hermeneutics of religion. Bloomington: Indiana University Press.

Kearney, R. 2010. Anatheism: Returning to God after God. New York: Columbia University Press.

Kombo, J. 2009. The trinity in Africa. Journal of Reformed Theology 3:125-143.

Kunhiyop, S.W. 2015. The Trinity in Africa: Trends and trajectories, In:

G.L. Green, S.T. Pardue \& K.K. Yeo (eds.), The Trinity among the nations, 55-68. Grand Rapids: Eerdmans.

Maimela, S.S. 1991. Black Theology and the quest for a God of liberation. In: S.G. Davaney (ed.), Theology at the end of modernity, 141-159. Philadelphia: Trinity Press International. 
Manoussakis, J.P. 2006. Introduction. In: Idem (ed.), After God, xv-xx. New York: Fordham University Press.

Marion, J-L. 1991. God without being. Chicago: Chicago University Press.

Marshall, B.D. 2004. Trinity, in G. Jones (ed.), The Blackwell companion to modern theology, 183-203. Oxford: Blackwell.

McFague, S. 1987. Models of God: Theology for an ecological nuclear age. London: SCM.

McFague, S. 1993. The body of God. London: SCM.

McGee, T. 2016. God's life in and as opening: James Cone, divine selfdetermination, and the Trinitarian politics of sovereignty. Modern Theology 32(1):100-117.

Moltmann, J. 1967. Theology of hope. London: SCM.

Moltmann, J 1969. The future as new paradigm of transcendence. In: J. Moltmann, Religion, revolution, and the future, 177-199. New York: Charles Scribner's Sons.

Moltmann, J. 1974. The crucified God. London: SCM.

Mostert, C. 2002. God and the future: Wolfhart Pannenberg's eschatological doctrine of God. London: T\&T Clark.

Muis, J. 2016. Onze Vader: Christelijk spreken over God. Zoetermeer: Uitgeverij Boekencentrum.

O'Collins, G. 1999. The holy trinity: The state of the questions, in S. Davis, D. Kendall \& G. O’Collins (eds.), The Trinity, 1-25. Oxford: Oxford University Press.

Pannenberg, W. 1971. God of hope. In: W. Pannenberg, Basic questions in theology, Vol 2, 234-249. London: SCM.

Pannenberg, W. 1991. Systematic Theology, Vol 1. Grand Rapids: Eerdmans.

Phan, P.C. 2011. Systematic issues in Trinitarian theology. In: P.C. Phan (ed.), The Cambridge companion to the Trinity, 13-29. Cambridge: Cambridge University Press.

Plantinga, R.J., Thompson, T.R. \& Lundberg, M.D. 2010. An introduction to Christian theology. Cambridge: Cambridge University Press. 
Pretorius, H. 2018. Is it possible to be a Reformed anatheist? In: C.D. van Troostwijk \& M. Clemente (eds.), Richard Kearney's anatheistic wager: Philosophy, theology, poetics, 142-153. Bloomington: Indiana University Press.

Price, R.B. 2011. The letters of the divine word: The perfections of God in Karl Barth's Church Dogmatics. London: T\&T Clark.

Rahner, K. 1997 (1970 Original Eng translation). The Trinity. New York: Crossroads.

Reeling Brouwer, R. 2011. Op zoek naar de waarheid: Het (systematisch) spreken over God gedurende de laaste eeuw. In: J.M. van't Kruis (ed.), Protestantse bronnen over God, 70-83. Zoetermeer: Uitgeverij Boekencentrum.

Rieger, J.2001. God and the excluded: Visions and blind spots in contemporary theology. Minneapolis: Fortress.

Rieger, J. 2007. Christ \& empire: From Paul to postcolonial times. Minneapolis: Fortress.

Rivera, M. 2007. The touch of transcendence: A postcolonial theology of God. Louisville: Westminster John Knox.

Rove, C.K. \& Hays, R.B. 2007. Biblical studies. In: J. Webster, K. Tanner \& I. Torrance (eds.), The Oxford handbook of Systematic Theology, 435455. Oxford: Oxford University Press.

Russell, R.J., Murphy, N. \& Stoeger, W.R. (eds) 2008. Scientific perspectives on divine action: Twenty years of challenge and progress. Vatican City: Vatican Observatory Publication; Berkeley: CTNS.

Sanders, F. 2012. The Trinity, in K.M. Kapic \& B.L. McCormack (eds.), Mapping modern theology, 21-45. Grand Rapids: Barker.

Schüssler Fiorenza, F. 2001. Being, subjectivity, otherness: The idols of God. In: J.D. Caputo, M.Dooley \& M.J. Scanlon (eds.), Questioning God, 341-369. Bloomington: Indiana University Press.

Schüssler Fiorenza, F. 2011. Systematic Theology: Task and methods. In: F. Schüssler Fiorenza \& J.P. Galvin (eds.), Systematic Theology: Roman Catholic perspectives 2nd ed, 1-78. Minneapolis: Fortress. 
Schwöbel, C. 1995. The Renaissance of Trinitarian theology: Reasons, problems and tasks. In: C. Schwöbel (ed.), Trinitarian Theology Today: Essays on Divine Being and Act, 1-30. Edinburgh: T\&T Clark.

Schwöbel, C. 2014. Where do we stand in Trinitarian theology? Resources, revisions, and reappraisals. In: C. Chalamet \& M. Vial (eds.), Recent developments in Trinitarian Theology: An international symposium, 9-71. Minneapolis: Fortress.

Shults, F.L. 2003. The futurity of God in Lutheran theology. Dialog 42(11):39-49.

Shults, F.L. 2005. Reforming the doctrine of God. Grand Rapids: Eerdmans.

Shults, F.L., Murphy, N. \& Russell, R.J. (eds.) 2009. Philosophy, science, and divine action. Leiden: Brill.

Smit, D. 2013. Quo vadis, sistematiese teologie? In: R. Vosloo (ed.), D.J. Smit Collected essays 5, Remembering theologians - doing theology, 387-398. Stellenbosch: Sun MeDIA.

Steenkamp, Y., 2017. Of poetics and possibility: Richard Kearney's post metaphysical God. HTS Teologiese Studies/Theological Studies 73(3), a4689. https://doi.org/10.4102/hts.v73i3.4689.

Swain, S.R. 2017. The Bible and the Trinity in recent thought: Review, analysis, and constructive proposal. Journal of the Evangelical Theological Society 60(1):35-48.

Swinton, J. 2011. Who is the God we worship: Theologies of disability; challenges and new possibilities. International Journal of Practical Theology 14:273-307.

Tanner, K. 2012. Social Trinitarianism and its critics. In: R.J. Woźniak \& G. Maspero (eds.), Rethinking Trinitarian theology, 368-386. London; T\&T Clark (Continuum).

Thiselton, A.C. 2015. Systematic Theology. Grand Rapids: Eerdmans.

Thomas, G., Reeling Brouwer, R.H. \& McCormack, B. (eds.), 2012.

Dogmatics after Barth. Leipzig: CreateSpace Independent Publication Platform. 
Tonstad, L.M. 2016. God and difference: The Trinity, sexuality, and the transformation of finitude. New York: Routledge.

Torrance, A.J. 2000. The Trinity, in: Webster, J. (ed.), The Cambridge companion to Karl Barth, 72-91. Cambridge: Cambridge University Press.

Tracy, D. 1994. The return of God in contemporary theology. Concilium 1994/6:37-46.

Tracy, D. 2000. The hidden and the incomprehensible God. Reflections (3):62-88.

Tracy, D. 2002. The impossible God: An interview with David Tracy (by L Malcolm). Christian Century. 13-20 Febr:24-30.

Tracy, D. 2011. Approaching the Christian understanding of God. In: F. Schüssler Fiorenza \& J.P.Galvin (eds.), Systematic Theology: Roman Catholic perspectives 2nd ed, 109-129. Minneapolis: Fortress.

Vähäkangas, M. 2000. African approaches to the Trinity. African Theological Journal 23(2):33-50.

Van den Brink, G. 2014. Social Trinitarianism: A discussion of some recent theological criticisms. International Journal of Systematic Theology 16(3):331-350.

Van den Brink, G, \& Sarot, M (eds.) 1995. Hoe is uw naam? Opstellen over de eigenschappen van God. Kampen: Kok.

Van den Brink, D. \& Van der Kooi, C. 2012. Christelijke dogmatiek. Zoetermeer: Uitgeverij Boekencentrum.

Vanhoozer, K.J. 2001. The love of God - its place, meaning, and function in Systematic Theology. In: K.J. Vanhoozer (ed.), Nothing greater, nothing better: Theological essays on the love of God, 1-19. Grand Rapids: Eerdmans.

Vanhoozer, K.J. 2005. Systematic Theology. In: Vanhoozer, K.J. (ed.), Dictionary for theological interpretation of the Bible, 773-779. Grand Rapids: Baker. 
Vanhoozer, K.J. 2010. Remythologizing theology: Divine action, passion and authorship. Cambridge: Cambridge University Press.

Venter, R. 2008a. God images, ethical effects and the responsibility of Systematic Theology. Acta Theologica 28(2):146-164.

Venter, R. 2008b. Trinity and Africa: The contribution of Charles Nyamiti. Word and Context (7):4-24.

Venter, R. 2012. Thinking about God today: Eavesdropping on four discourses. NGTT 53 Suppl 3:195-204.

Verhoef, A. 2017. The relevance of Continental Philosophy of Religion for theology in contemporary South Africa. Acta Theologica 37(2): $168-187$.

Volf, M. 1998. “The Trinity is our social program": The doctrine of the Trinity and the shape of social engagement. Modern Theology 14:403423.

Volf, M. 2011. Allah: A Christian response. New York: HarperCollins.

Walls, A.F. 2002. The cross-cultural process in Christian history. Maryknoll, NY: Orbis.

Webster, J. 2003. Holiness. Grand Rapids: Eerdmans.

Webster, J. 2007. Introduction: Systematic Theology. In: J. Webster, K. Tanner \& I. Torrance (eds.), The Oxford handbook of Systematic Theology, 1-15. Oxford; Oxford University Press.

Weinandy, T. 2000. Does God suffer? Edinburgh: T\&T Clark.

Wisse, M 2011. Trinitarian theology beyond participation: Augustine's De Trinitate and contemporary theology. London: T\&T Clark.

Wolterstorff, N.P. 2006. Is there justice in the Trinity? In: M. Volf \& M. Welker (eds.), God's life in Trinity, 177-187. Minneapolis: Fortress.

Yong, A. (with J.A. Anderson), 2014. Renewing Christian theology: Systematics for a global Christianity. Waco, Texas: Baylor University Press.

Zizioulas, J. 2008. Lectures in Christian Dogmatics. London: T\&T Clark. 